International

Medical Society

http://imedicalsociety.org

\title{
Repercussion of Segregation in the Lives of Children Separated by Leprosy
}

Mônica Gisele Costa Pinheiro1, Bruna Rodrigues Monteiro², Eliabe Rodrigues de Medeiros ${ }^{1}$, Fernando de Souza Silva ${ }^{3}$, Clélia Albino Simpson', Francisco Arnoldo Nunes de Miranda1, Ana Michele de Farias Cabral ${ }^{1}$, Felismina Rosa Parreira Mendes ${ }^{4}$

\section{Abstract}

Introduction: Leprosy is a disease that carried the characteristic of incurable and disfiguring for years, causing the social segregation of patients before the family and society.

Objective: To describe the repercussion of segregation in the lives of children separated by leprosy who lived in Oswaldo Cruz School.

Method: This is a qualitative study with the methodological referential Oral History of Life. The sample consisted of 52 family members of former patients segregated in the São Francisco of Assis Cologne Hospital, registered in the Reintegration Movement of People Affected by Leprosy in RN (MORHAN Potiguar). The network was structured from the zero point and consists of ten collaborators. Data were collected through individual interviews, which were recorded, transcribed and submitted to thematic content analysis.

Results: Emerged four themes: broken ties (broach the consequences in family relationships established by the experience of having a relative affected by leprosy); stigmatized (emphasize the obstacles in social relationships experienced by family member of leprosy former patients, who although healthy, were victims of social exclusion, stigma and prejudice); primary school (reveals the bad treatment experienced in Oswaldo Cruz School, as well as the resilience process of education received); from leprosy to Hansen's disease (were presented reflections made by collaborators related to leprosy control policy in the past and present).
1 Nursing Department of the Federal University of Rio Grande do Norte, Natal, RN, Brazil.

2 Hospital of the Federal University of Pernambuco, Recife, Brazil.

3 Onofre Lopes University Hospital of the Federal University of Rio Grande do Norte, Natal, RN, Brazil.

4 School of Nursing St. John of God of University of the Évora, Portugal.

Contact information:

Eliabe Rodrigues de Medeiros.

झ eliabe.medeiros@hotmail.com 
Conclusion: It was evidenced that isolation has influenced the lives of the study participants. The historical marks lived (experienced) in the past are still present in the collaborators memory and directly reflected in thinking about leprosy today.

\section{Keywords}

Leprosy; Social Isolation;

Social Stigma.

\section{Introduction}

Leprosy, also known as leprosy or Hansen's disease, is considered one of the oldest diseases in human history. It carried the characteristic of an incurable and disfiguring disease for years, causing the social segregation of patients before the family and society [1].

The disease not only castigates the contaminated but also their close contacts, as their families, although healthy, went to be treated as suspected cases of the disease and subsequently were isolated from the rest of the population $[2,3]$.

The disease control measure ruled in the isolation of people with leprosy in Brazil is reported since the nineteenth century, in the colonial government of $D$. João $V$. This practice has become more common in 1930 and 1945, when a tripod structured by the dispensary, leprosarium, and school/preventorium supported prophylaxis of the disease, which were strengthened by the National Plan to Combat Leprosy [4].

In the dispensary, people received the disease diagnosis and confirmed cases followed to isolation in leper colonies, in a mandatory way, while schools had care, education, and observation of the children of leprosy carriers [2]. The structure adopted by the government resulted in the removal of the leprosy patients of their minor children, who have received care in schools, as the 7758 Decree-Law number, of 11 November 1938, staying in the institution until adolescence [5].

In the state of Rio Grande do Norte, the São Francisco colony (1929-1994) served as a stage for the isolation of people with leprosy. The children of patients life was destined to Oswaldo Cruz School located in the city of Natal [6].

The adopted measures disregarded the social relations of people with the disease, breaking family ties and impacting the lives of patients and their children [5]. The consequences of the children isolation separated both in the psychological, as in the social and family aspect are described in a study conducted in the State of Rio Grande do Norte, which represents the life trajectory of 10 children of institutionalized leprosy patients in preventoriums/ schools [6].

The importance of studying the theme refers to the expectation of continuing news reports about the possible isolation consequences of those who did not developed the disease, but remained cloistered in the Oswaldo Cruz School. In an attempt to contribute to the dissemination of the experienced problems, the following question was elaborated: Which is the impact of segregation in the lives of children of leprosy patients who lived in Oswaldo Cruz School?

To answer this question, the study aims to describe the repercussion of segregation in the lives of children separated by leprosy who lived in Oswaldo cruz School.

\section{Method}

This is an exploratory, descriptive study, with a qualitative approach and with the methodological referential Oral History of Life.

The Oral History of Life provides an understanding of the impact experienced by those individuals who 
carry with them the marks left by the resulting leprosy family separation and segregation in schools, enhancing their life experiences, because it refers to the narrative where the subject has freedom to chain their story, revealing or hiding experienced facts. The narrator is free to report their personal experience and is called developer [7].

The collaborators were selected in the existing register on the Reintegration Movement of People Affected by Leprosy in RN (MORHAN Potiguar), in which there were 52 members, all relatives of leprosy former patients. The zero point of this study was the one that stayed longer in the school. Through the zero point, specific questions emerged, where the interviewed collaborator suggested other people to compose the network, constituting a total of ten individuals.

All collaborators were subjected to the following eligibility criteria: be former internal the Oswaldo Cruz School; residing in Natal during the period of data collection; and have a voluntary willingness to participate in the study by signing the Informed Consent Form, considered an ethical and fundamental methodological condition. Collaborators who were absent on the day of the interview and individuals with barriers to communication that could impair the effectiveness of the interview have been excluded.

Before the interview, there was the pre-interview, contacting each collaborator to explain the research objectives, as well as schedule the day, time and place to hold the interview. Data collection occurred during the months of June and July 2014, through individual interviews, by using the network identification tool and open questions that linked the memories of collaborators for the purpose of research.

The audio recorder recorded the reports and interviews lasted on average 1 hour. Part of them took place in a meeting room in the city center while other collaborators chose to be interviewed in their homes. With possession of written reports, it continued with the development of text transcrip- tion in full, textualization, transcreation, the conference of the written material by each collaborator, followed by its authorization use by signing the assignment letter [7].

The results were analyzed and organized according to the content analysis technique [8], to capturing the significant content, striking and challenging for each collaborator.

This study was approved by the Ethics in Research Committee of the Federal University of Rio Grande do Norte through the Opinion number 650.654/2014 and CAAE 25922214.3.0000.5537.

To preserve the anonymity of the collaborators, it was decided to identify them by color names: Red, Blue, Green, Yellow, Orange, Black, Purple, Brown, Pink and White.

\section{Results and discussion}

Ten subjects were interviewed, three male and two female. The age group ranged between 58 and 76 years old. Regarding the level of education, two collaborators had completed elementary school; two attended high school; and one completed higher education. Regarding the profession, two were retired, and the other performed activities that developed when internal, working as a seamstress, painter, and craftsman. As for family income, four subjects had a monthly income between one and two minimum wages and one received monthly five minimum wages, based on the current value of the Brazilian minimum wage, during the search of $R \$$ 724.00 .

The trajectory of school life with the consequent level of training and profession of the collaborators were strongly influenced by the reclusion in the primary school. The bylaws of schools provided access to primary education for children who resided there, leaving those who manifest an interest to continue their studies pay their expenses [9].

After analyzing the reports of the life stories of the thematic analysis of content technique [8], 
commonalities were identified in the statements of collaborators that led to four main themes, namely: broken ties; stigmatized; primary school; from leprosy to Hansen's disease. The speeches were placed on the discussion topic of the respective theme.

\section{Broken ties}

Public health adopted the practice of compulsory isolation of leprosy patients in community hospitals, located in remote areas, as a prophylactic measure to protect the health of the healthy population [10]. The isolation of sick parents in colony-hospitals put into question the destiny of children who, although they had not the disease, were ignored by family and society because they fear the possibility of children act as a source of contagion, creating stigma [5].

It was up to the State to adopt primary schools to give shelter to the "orphans of living parents", preventing the abandonment of children, while it reduced its contact with the patient [10].

The separation between parents and children on the occasion of the disease resulted in the breakdown of the family structure while the separated children only had the right to see their parents at a distance considered as a safety zone, which was not always possible, as reported below.

I think the first visit I made to my father was about six months after I went to primary school. He stood there in the colony and to talk to him it had to be on the windward side. We had to greet far because he had the disease and could not shake hands.

Blue.

At the time I lived in primary school, I could not go to see and embrace my parents because I was a child and would not let me go.

Brown
Internment influenced a lot in our relationship ... Both with father as with mother, because we are more distant, separated without contact.

Pink.

In all interviewed reports, the father was presented as the main family member affected by leprosy, but the mother, despite not having the disease, remained away from the primary school and living together with children. It is observed that both separations affected the lives of institutionalized people, which express the feeling of loneliness because they have grown up in the Hearth, not considering with family members.

If it were not for the hospitalization, everything would be different because my father was a very good person, very affectionate and, as he was isolated, we missed this affection.

Green.

That is why the relationship of us changed and the family were all far. My grandmother and grandfather in the colony in Macaiba.

Purple.

I was many years separated from my family. As my father was isolated, we kept away from him. And we were separated, we were without the father, without the mother, and with no one, because the law said it was to stay separated.

Yellow.

After the hospitalization, I was far from my father and my mother. Even today there is this separation! The other daughters of her, from another marriage, do not have me as a brother. Their daughters, who are my nieces, they have me as an uncle.

Orange.

Some close relatives, who were temporarily responsible for the children, walked to the adoption or 
the primary school for being daughters of lepers, and they fear the possibility of contagion. Thus, even without presenting the disease, they also lived reclusive, isolated in schools, like their parents in colonies [11, 12].

\section{Stigmatized}

The fact that they are children of parents affected by leprosy with conclusive admission in primary school provided the exclusion of interns of life in society. The population identified this child as a patient relative with leprosy, acting with discrimination, stigma and social exclusion [11].

The children of leprosy victims felt the presence of stigma, triggering signal of emotion that causes immediate separation forward to a different group, and can lead to the self-isolation, search also stigmatized people and formation of associations between them, building a social identity [12].

The fear of the judgment of society and the absence of a structural base represented by the family made the institutionalized constitute links between them, groups with the same characteristics, forming a kind of defense and self-help. Institutionalized children and the population had as domain the fear of what the unknown.

I was engaged with a person from there, internal like me... I was so afraid to get out of there, that I spent engaged six years to be able to get married and go to live outside the school. I felt very afraid of things in the world, afraid of what the people might talk about us because I was the son of a leper.

Green

People outside the school want to know why people live there. And when we began to talk, they said: "Oh, it's because you are all son of a leper.", and thus distanced them from us.

Orange.
The defects in the body of my father were easily seen and marked all of us family and people also had prejudice against us.

Black.

In the case of leprosy, stigma was linked to bodily deformities caused by the action of $\mathrm{M}$. leprae in the body, which generated disabilities and exclude their holders from society [13]. This stigma exceeded the scars of the patients and also reached their families, especially children, even not carrying the disease [14].

The literature reports that the return of the interns to their home, after separated years, causes a feeling of not belonging to the family, and estrangement, which today is expressed by physical and emotional detachment [5]. However, it is noteworthy that the distance of their parents, and the reclusive life in school and the judgment of society, underpinned union ties and friendships within the institution, providing opportunities for the formation of a new family.

\section{Primary school}

Despite the drawbacks found in front of family separation and hospitalization, the school was an institution that housed the healthy children by providing them with education. In general, the institution was dedicated to the care, education, and observation of the children of persons affected by leprosy, representing a form of boarding school [5].

The education provided by the school, as portrayed in the collaborators reports, generated a satisfaction to those who had no perspective for the future, and also the development of knowledge in the field of painting, sewing and carpentry. These learning have been reported with a positive view of the institutionalized years. 
As I learned to sew, I stayed in the sewing room and helped other sewing clothes, preaching buttons... The school nuns had contact with outsiders and got things for us to do, such as painting and embroidery. So we learned a lot.

Green.

We studied! In this aspect, I am very grateful! Because inside we hardly would study because it had no... Education, lessons...so it was not all bad. I made the secondary school there and learned profession. I am a cabinetmaker. My first profession was carpentry.

Blue.

The school has left memories of thanks to the collaborators of the research, by the opportunity to initiate studies and conducting courses during the hospital stay. In nonsense, sometimes the hard work prevailed regarding the studies, which were interrupted to run adult tasks. Another factor observed in the reports is the existence of mistreatment.

When we concluded the primary, we could not study because it was missing our work in primary school and so I spent 17 years without studying. In school, we concluded the primary and could not continue studying because it would have to be in an outside school, and we could not leave because they needed our services.

Red.

We worked... We were a lot of boy going to hard work. To make a fence, hoeing... For nothing!.

Blue.

There was very bad, had many punishments! If rang the bell for lunch and if you were late, stayed without food.... And just ate if you were with the slipper! I've been hungry for not being there with the slipper.

Orange.
It is emphasized that the treatment of employees with internal was based on a strict methodology. Children separated by leprosy were often mistreated, having to follow the received orders and have the discipline to perform certain developed activities [6].

There was no renunciation of the past to collaborators, even amid moments of sadness and anger, but overcoming the obscure life due to the disease that stigmatized them. Consistent with resilience, overcoming process in a positive way that the subject takes in the midst of adversity, developing skills in the pursuit of quality of life [15].

\section{From leprosy to Hansen's disease}

It is observed that there is a dichotomy between leprosy of the past and Hansen's disease in the present, separated by a watershed called polychemotherapy, which provided a cure for the disease.

The history of leprosy carries taboos, symbolic beliefs, and prejudices that stigmatized the patient. Often associated with the notion of sin, the signs and symptoms of the incurable disease generated aversion and rejection of the sick, culminating in their social isolation and personal suffering [16].

With the development of the pharmaceutical industry, discovery and introduction of specific polychemotherapy, the term "Hansen's disease" was adopted to replace the "leprosy" denoting a scientific vision for the disease. The new nomenclature comes from a tribute to the Norwegian physician Gerhard H. A. Hansen, who identified the bacillus that causes the disease [17]. The new therapeutic modified disease control policy, ending the compulsory isolation, which was replaced by outpatient treatment [18].

The change in treatment caused significant changes in the context of the disease, which came to be regarded as curable and without the need for isolation. The collaborators of the study, as the fo- 
llowing reports, evidenced this change of inherent interpretation to the disease:

The word "leprosy" is very heavy, was part of our life because it separated the whole family. At that time we did not say Hansen's disease it was leprosy and was very heavy.

Green.

Today is different, because leprosy has medication and cure. The treatment is better, it is done at home ... You can get together with everyone.

White.

Now everything is different! Hansen's disease is a normal disease and child can be created with the patient! Before it was in the colony, we had all the impact, and today the treatment is done at home and has the cure!

Before the episodes of stigma, prejudice, and exclusion experienced by the collaborators of the study, reflecting about leprosy, today, they reported that the disease has treatment and cure. However, it is necessary to emphasize that it is still associated with the disease characteristics in the past, such as stigma and social exclusion, promoting fear and revulsion in people [19].

The mystical representation of impurity, sin, mutilations and deformities caused stigma that solidified sociocultural situation about the leprosy patient. The infectious nature of the disease contributed to the patient's isolation practices, with irreparable consequences in the lives of affected individuals and their families [3]. The image of the disease before the existence of polychemotherapy creates insecurity and difficulty in social contact, endangering the issue of self-care of leprosy patients, and interpersonal relationships [20].

It is noteworthy that the transmission and infection by $\mathrm{M}$. leprae is related to social and economic factors such as nutritional status, hygiene, housing and living condition. Thus, the risk of falling ill increases in situations of social inequalities, featuring the endemicity of the disease as a significant public health problem [21].

The misinformation about leprosy characteristics influence the behavior of people in front of the patient, requiring a therapeutic process that encompasses not only the pathological picture but also the mutual involvement of relatives, with possible questions for clarification. Thus, requiring interventions of health professionals with educational activities $[20,22]$.

\section{Final Considerations}

The written record of memories took place through an oral and facial expression of feelings of grief and sadness at the experiences of collaborators of the study, which carried with them the scars left by leprosy, who are present today.

In the study, it is observed that this public health policy in Brazil served as the main responsible for the separation and the inhuman treatment of internal children, which influenced the life of the study collaborators with memories of child labor, suffered punishment and the lack of family structure, many of whom could not be reintegrated into the family after they left primary school, requiring the strength to build a new life.

All these moments were determinant to question the isolation of those who did not develop the disease and the consequences generated in both aspects of their life, psychologically and socially. While there is recognition of the existence of the cure for leprosy without the need for isolation, experienced historical marks in the past are still present in the minds of the collaborators and directly reflected in thinking about leprosy today.

Therefore, these results become relevant to reflect forward the strategies adopted by health professionals and need to be sensitive to the social implications that leprosy has generated in the past and 
continue to perpetuate today, during the treatment of patients and their families. It is noteworthy that the theme is not only important for the understanding of leprosy issues but may have coverage for health policies in the country.

One limitation of the study is the composition of the collaborators network from suggestions of zero collaborator, as proposed by oral history, which can lead to a bias in the study because they should be known and share the same feelings about the isolation process in primary school.

\section{References}

1. Nunes JM, Oliveira EM, Vieira NFC. Hanseníase: conhecimentos e mudanças na vida das pessoas acometidas. Ciênc. saúde coletiva. 2011; 16(supl.1):1311-8. Disponível em: http://www. scielo.br/pdf/csc/v16s1/a65v16s1.pdf

2. Souza JFM, Sena TCCB. O envelhecer institucionalizado de sujeitos sequelados pela Hanseníase da U/E Abrigo João Paulo II. Rev. Kairós. 2014; 17(1):103-23. Disponível em: http://revistas. pucsp.br/index.php/kairos/article/view/19879/14790

3. Videres ARN, Simpson CA, Mendes FRP, Oliveira RCC, Adário KDO, Pimenta EF et al. Manifestations of stigma and prejudice informed by treated lepers. International Archives of Medicine. 2016; 9(47):1-10. Disponível em: http://imed.pub/ojs/index.php/ iam/article/view/1453/1176

4. Genovez PF, Pereira FR. Da lepra à Hanseníase: política pública, o cotidiano. HistQuestoes Debates. 2014; 60(1):205-28. Disponível em: http://ojs.c3sl.ufpr.br/ojs/index.php/historia/ article/view/38287/23434

5. Almeida SSL, Savassi LCM, Schall VT, Modena CM. Maternidade e hanseníase: as vivências de separação devido ao isolamento compulsório. Estud. psicol. (Natal). 2012; 17(2):275-81. Disponível em: http://www.scielo.br/pdf/epsic/v17n2/11.pdf

6. Lima IB, Cabral AMF, Simpson CA. Hanseníase e a negação da história: trajetória de filhos separados. Rev. enferm. UFPE online. 2013; 7(5):4340-7. Disponível em: http://www.revista.ufpe. br/revistaenfermagem/index.php/revista/article/view/4603/ pdf 2715

7. Meihy JCSB, Holanda F. História oral: Como fazer, como pensar. São Paulo: Contexto; 2011.

8. Silva PA, Thauana IN, Brandalize RDL. Metodologias de ensino utilizadas por docentes do curso de enfermagem: enfoque na metodologia problematizadora. Enferm. glob. 2015; 14(1):13652. Disponível em: http://revistas.um.es/eglobal/article/ view/186291/169011
9. Presidência da República (BR). Secretaria de Direitos Humanos. Relatório Preliminar Grupo de Trabalho Interno:Filhos segregados de pais ex-portadores de hanseníase submetidos à política de isolamento compulsório. 2012. Disponível em: http://www. morhan.org.br/views/upload/relfilhossep.pdf

10. Santos VSM. Filantropia, poder público e combate à lepra (19201945). Hist. ciênc. saúde-Manguinhos. 2011; 18(Supl.1):253-74. Disponível em: http://www.scielo.br/pdf/hcsm/v18s1/14.pdf

11. Penchaszadeh VB, Faccini LS. Genetics and human rights. Two histories: Restoring genetic identity after forced disappearance and identity suppression in Argentina and after compulsory isolation for leprosy in Brazil. Genet. mol. biol. 2014; 37(Supl.1):299-304. Disponível em: http://www.scielo.br/pdf/ gmb/v37n1s1/v37n1s1a16.pdf

12. Meyer TN. Casa de Saúde Santa Fé: breve história de uma excolônia de hanseníase. Rev. méd. Minas Gerais. 2010; 20(4):61221. Disponível em: http://www.rmmg.org/exportar-pdf/348/ v20n4a19.pdf

13. Simpson CA, Miranda FAN, Meneses RM, Carvalho $I H$, Cabral AMF, Santos VRC. Within the habitus of the former colony hospital: social representations of leprosy. Rev. pesqui. cuid. fundam. (Online). 2013; 5(3):104-13. Disponível em: http://www.seer.unirio.br/index.php/cuidadofundamental/ article/view/3003/pdf 825

14. Santos PN, Zerbinato PHM, Silva AM, Rodrigues DP, Oliveira, LS, Antunes $C E$, et al. Detecção da hanseníase e a humanização do cuidado: ações do enfermeiro do programa de saúde da família. Enferm. glob. 2012; (25):116-28. Disponível em: http://scielo. isciii.es/pdf/eg/v11n25/pt docencia1.pdf

15. Lettnin C, Zacharias J, Mendes AR, Dohms KP, Mosquera JJM, Stobaus CD. Resiliência e educação: Aportes teórico-práticos para a docência. Revista Contrapontos. 2014; 14(2):322-38. Disponível em: http://siaiap32.univali.br/seer/index.php/rc/ article/view/4756/pdf 35

16. Lima IB, Simpson CA, Cabral AMF. Limitação de atividades e participação social em pacientes com hanseníase. Rev. enferm. UFPE online. 2014; 8(4):994-1001. Disponívelem: http://www. revista.ufpe.br/revistaenfermagem/index.php/revista/article/ view/4499/pdf_4928

17. Santos AK, Ribeiro APG, Monteiro S. Hanseníase e práticas da comunicação: estudo de recepção de materiais educativos em um serviço de saúde no Rio de Janeiro. Interface comun. saúde educ. 2012; 16(40):205-18. Disponível em: http://www.scielo. br/pdf/icse/v16n40/aop1412.pdf

18. Opromolla PA, Laurenti R. Controle da hanseníase no Estado de São Paulo: análise histórica. Rev. saúde pública. 2011; 45(1):195203. Disponível em: http://www.scielo.br/pdf/rsp/v45n1/1764.pdf 
19. Batista TVG, Vieira CSCA, Paula MAB. A imagem corporal nas ações educativas em autocuidado para pessoas que tiveram hanseníase. Physis (Rio J.). 2014; 24(1):89-104. Disponível em: http://www. scielo.br/pdf/physis/v24n1/0103-7331-physis-24-01-00089.pdf

20. Souza IA, Ayres JA, Meneguin S, Spagnolo RS. Autocuidado na percepção de pessoas com hanseníase sob a ótica da complexidade. Esc. Anna Nery Rev. Enferm. 2014; 18(3):510-4. Disponível em: http://www.scielo.br/pdf/ean/v18n3/1414-8145ean-18-03-0510.pdf

21. Masuchi $M H$, Filipini $R$, Corrêa $A Z A H$, Benetti FA, Ito $L M$, Savoldi AS et al. Clinical-epidemiological profile of patients living with leprosy. International Archives of Medicine. 2015; 8(208):1-9. Disponível em: https://docs.google.com/viewerng/ viewer?url=http://imed.pub/ojs/index.php/iam/article/ viewFile/1261/998

22. Cid RDS, Lima GG, Souza AR, Moura ADA. Percepção de usuários sobre o preconceito da hanseníase. Rev. RENE. 2012; 13(5):1004-14. Disponível em: http://www.revistarene.ufc.br/ revista/index.php/revista/article/viewFile/1158/pdf

\section{Publish in International Archives of Medicine}

International Archives of Medicine is an open access journal publishing articles encompassing all aspects of medical science and clinical practice. IAM is considered a megajournal with independent sections on all areas of medicine. IAM is a really international journal with authors and board members from all around the world. The journal is widely indexed and classified Q1 in category Medicine. 